Language in Africa 1(3), 2020, 155-180. doi: 10.37892/2686-8946-2020-1-3-155-180

\title{
THE PHONOLOGY AND NOUN MORPHOLOGY OF YI KITULE, AN ADAMAWA LANGUAGE OF EAST-CENTRAL NIGERIA
}

\author{
Roger Blench \\ McDonald Institute for Archaeological Research / University of Cambridge \\ rogerblench@yahoo.co.uk
}

\begin{abstract}
The paper describes the phonology and nominal morphology of Kitule, an Adamawa language of the Tula-Waja group, spoken in East-Central Nigeria. Kitule has a restricted consonant inventory, marked by a loss of voicing contrast in most consonants. It has a system of ATR vowel harmony, which has begun to erode in many lexical items. There are three level tones plus rising and falling glides. The underlying system of nominal number marking is suffix alternation as with the other languages in the group, but this has undergone numerous alterations, in part due to the addition of prefix alterations, and fossilised suffixes which have been incorporated into the stem. Some of these then appear as infixes, although this is not the underlying system. A note on demonstratives is appended, which shows that these are not directly concordial, but which have a broad semantic logic.
\end{abstract}

Key words: Kitule, Adamawa, phonology, nominal morphology

\section{Introduction}

The Kitole [Tula] language is spoken in Nigeria, Gombe state, Kaltungo LGA, $30 \mathrm{~km}$ east of Billiri. It forms part of the "Tula-Waja group", a subgroup of the Adamawa languages, first identified by Greenberg (1963: 9) who listed it as Group 1 of his proposed "Adamawa Eastern" subgroup of Niger-Congo. Later in the same decade, Jungraithmayr (1968/1969) provided some basic morphological information about some of the languages in this subgroup. These arguments have been reprised in the work of Kleinewillinghöfer (1996a; 1996b). In 2014, Kleinewillinghöfer circulated a comparative wordlist 
of the group, which provides evidence for its coherence, and included three dialects of Tula, Kitole, Baule and Yili. Boyeldieu (1980) had no original field data on Tula, but his study of the nominal affix alternations compared them to Niellim, suggesting that the morphological arguments for an Adamawa branch of Niger-Congo could be supported by similarities in form across its entire geographical range.

The Tula people have been the subject of limited anthropological interest, for example in Huggins (1925), CAPRO Research Office (1995) and Gebauer (1996), but these accounts are very fragmentary. The title of Hall (1944) "From cannibalism to Christ" speaks for itself. The Tula language itself was first described in the grammar sketch by an anonymous missionary, written up by Lukas (1955/1956). This is problematic on vowels and omits tone, but still constitutes a useful base document. Kleinewillinghöfer (2006) is a brief description of the infix system of plural formation in Tula. Finally, Mu'azu \& Polo (2015) have published what they claim to be a "Modern Tula Dictionary". As usual with the lead author, this is a problematic piece of work which is best described as vanity publishing; no further reference will be made to it.

Kitole has long been the subject of a literacy project, and the finalisation of a New Testament is said to be underway. An anonymous draft wordlist was prepared in conjunction with the literacy project for Kitole, apparently printed out from a draft Bible translation, but with no marking of vowel distinctions and no tones and few plurals. Roger Blench and Musa Tula worked on the list, adding new lexical items, transcriptions and plurals (Blench \& Tula 2009). This work was not finalised, but a draft of this dictionary has been in circulation for some time. The present paper is therefore a write-up of this work as it stands; increasing insecurity in the region has not made it possible to check some outstanding items.

The paper attempts to make use of standard linguistic terminology in the descriptions, similar to other accounts of Adamawa languages, for example Kleinewilllinghöfer (1991). It treats the basic phonology paying particular attention to the system of ATR vowels such as 
described in Casali (2008). Niger-Congo is well-known for its system of noun-class alternations (Greenberg 1977), most commonly prefixing, but in the case of Gur and Adamawa, consisting of alternating suffixes. The erosion of such systems is widely documented in Adamawa languages with a wide variety of disparate outcomes (Boyd 1989).

\section{Kitzle Phonology}

\subsection{Vowels}

2.1.1. Vowel inventory

Kitole probably has nine phonemic vowels (see Table 1).

Table 1

Vowel system of Kitole

\begin{tabular}{|c|c|c|c|}
\hline & Front & Central & Back \\
\hline Close High & $\mathrm{i}$ & {$[\mathrm{u}]$} & $\mathrm{u}$ \\
\hline Close high-mid & I & & U \\
\hline Close-Mid & $\mathrm{e}$ & ə & \\
\hline Open-Mid & & & כ \\
\hline Open & & $\mathrm{a}$ & \\
\hline
\end{tabular}

These must originally have been arranged in strict \pm ATR vowel harmony sets, as is still the case with some neighbouring languages such as Yebu. A feature of the phonology is the extreme rarity of back vowels; the vast majority of vowels are front or central. The contrast between $/ 0 /$ and $/ 0 /$ has disappeared, and indeed $/ 0 /$ is very rare and [o] has only been recorded in two words. Vowel harmony appears to operate in the stems, principally between the two front vowels i/e and $\mathrm{I} / \varepsilon$. $/ \mathrm{I} /$ is often centralised and is hard to distinguish from $/ \mathrm{\partial} /$. However, any vowel can pair with the central vowels $/ \mathrm{a} /$ and $/ \mathrm{a} /$ and these no 
longer form a pairing but can occur in the same word. Unresolved is the issue of whether a third central vowel is developing. Some words appear to have $[\mathrm{u}]$ in contrast to $/ \mathrm{a} /$ and $/ \mathrm{a} /$. It has not yet been established whether this is phonemic.

\subsubsection{Vowel length}

Kitule appears to have a restricted set of doubled vowels; only /aa/, /ee/, /ii/ and /uu/ have been recorded. These are bimoraic sequences of like vowels, as may be seen from the fact that they often bear two different tones. It is presumably significant that doubled vowels only occur with the expanded +ATR vowels and never with the -ATR vowels. Examples of contrast are as follows.

$\mathrm{a} \sim$ aa

kár 'headpad' kàár 'pied crow'

kwal 'flute' $\quad$ kwaal 'planting'

$\mathrm{e} \sim \mathrm{ee}$

fe 'pay' $\sim$ feer 'to stretch out, expand'

i ii

dì 'to finish' $\sim$ dì 'sky'

kì 'to cry out, shout' $\sim$ kî̀ 'ladle'

$\mathrm{u} \sim \mathrm{uu}$

dùm 'to bite' $\quad \sim$ dúúm 'seeds kept for planting'

kù 'to flay, to skin' $\sim$ kùú 'farm'

\subsubsection{Vowel + approximant sequences}

Kitole has V+y sequences, which only occur as a final syllable in both singulars and plurals (Table 2, Table 3). The assumption is that these are former $-I$ suffixes which have lost their tone. 
Table 2

KItole - Vy sequences in singulars

\begin{tabular}{lll} 
sg. & pl. & Gloss \\
\hline bajay & - & 'misunderstanding' \\
kàkway & kakwáti & 'tribal mark' \\
kàsway & kàswati & 'tailor ant' \\
kóy & kóóbí & 'charcoal' \\
\hline
\end{tabular}

Table 3

KItole - Vy sequences in plurals

\begin{tabular}{lll} 
sg. & pl. & Gloss \\
\hline bwàmbè & bwantrbwéy & 'antelope' \\
carks & cartukəy & 'okra' \\
kàlta & kàltàtay & 'cat' \\
kànà & kànay & 'scorpion' \\
kùlè & kùley & 'boil on skin' \\
kwase & kutay & 'calabash' \\
luke & lukey & 'dress' \\
\hline
\end{tabular}

\subsection{Consonants}

\subsubsection{Inventory}

The Kitule consonant inventory is fairly restricted. Voiceless and voiced stops are in complementary distribution, voiceless word-initially, and free variation between voiceless and voiced intervocalically. This is very rare for Nigerian languages as a whole. Kitule consonants are as follows (see Table 4).

Voicing contrasts have been effectively lost for some plosives and fricatives, typically $[\mathrm{z}],[\mathrm{d}],[\mathrm{v}],[\mathrm{p}]$ and $[\mathrm{g}]$, with voiced counterparts only appearing as free variants in intervocalic position. Contrast is maintained for the alveolars [d] and [t]. Thus: nùke nùge 'grandmother', bákásì bágázì 'baboon', dwákà dwágà 'melon'. 
Table 4

\section{Consonant system of Kitole}

Bilabial Labiodental Alveolar Palatal Velar Labial

Plosive $\quad b$

$\mathrm{t}$

d

$\mathrm{k}$

Nasal

$\mathrm{m}$

$\mathrm{n}$

n $\quad$ g

Fricative

$\mathrm{f}$

S

Affricate

Approximant

y

W

Tap

Lateral

Approximant

No free variation was noted for some examples where $[b]$ is intervocalic position: dìbìdù 'question', drbíl 'road vehicle'. More testing will be required to establish the exact distribution of free variation.

$\mathfrak{t} \sim \int$ are in free variation in word-initial position. Thus: t fir $\sim$ fir 'come out'.

Deletion of vowels at morpheme boundaries and subsequent assimilation has resulted in occasional geminates or doubled consonants. Examples of all those recorded so far are as follows (see Table 5).

Table 5

\section{Examples of geminated consoants in Kitole}

\begin{tabular}{|c|c|c|c|}
\hline C & sg. & pl. & Gloss \\
\hline $\mathrm{bb}$ & dìr & dìbbù & 'fool' \\
\hline $\mathrm{tt}$ & kàtàttàkè & kàtàttàkèti & $\begin{array}{l}\text { 'shallow part of a pond } \\
\text { or lake' }\end{array}$ \\
\hline $\mathrm{nn}$ & kùn & kúnní & 'mountain' \\
\hline yy & yupge & yüi & 'hoe' \\
\hline 1 & kàdwàllè & kàdwàllètı & 'kidney' \\
\hline
\end{tabular}


Such examples are rare but it seems that free variation is less common and it is the voiced counterpart which is realised.

\subsubsection{Labialisation}

Kitule permits labialisation of most consonants, although examples are extremely rare for some. The consonants that are labialised are as follows; b, d, f, k, l, m, n, r, s, t, y. The examples below provide evidence for contrasts.

$\mathrm{b} \sim \mathrm{bw}$

bà 'to look for, to seek, to search' $\sim$ bwà 'death'

bàl 'thick beer made from guinea-corn' bwàl 'moulded balls

báy 'mountain'

bwàn 'hole'

bàr 'to hide behind a person'

bwàr 'to be difficult'

$\mathrm{d} \sim \mathrm{dw}$

dál 'to fold' dwàl 'to wound'

dààkù 'thief' $\quad$ dwaku 'rope'

$\mathrm{f} \sim \mathrm{fw}$

fár 'to put' $\sim$ fwar 'to be sour'

fèbu 'all' $\quad$ fwèbu 'quickly, rapidly, soon'

$\mathrm{k} \sim \mathrm{kw}$

kár 'headpad' kwár 'embrace'

kada 'dog' kwàdà 'stool, excrement, faeces, dung, manure'

kí 'to break' $~ k w i$ 'describes light-coloured skin'

$1 \sim 1 \mathrm{w}$

$l \varepsilon$ 'sheath' $\sim$ lw⿳亠े 'enough' 


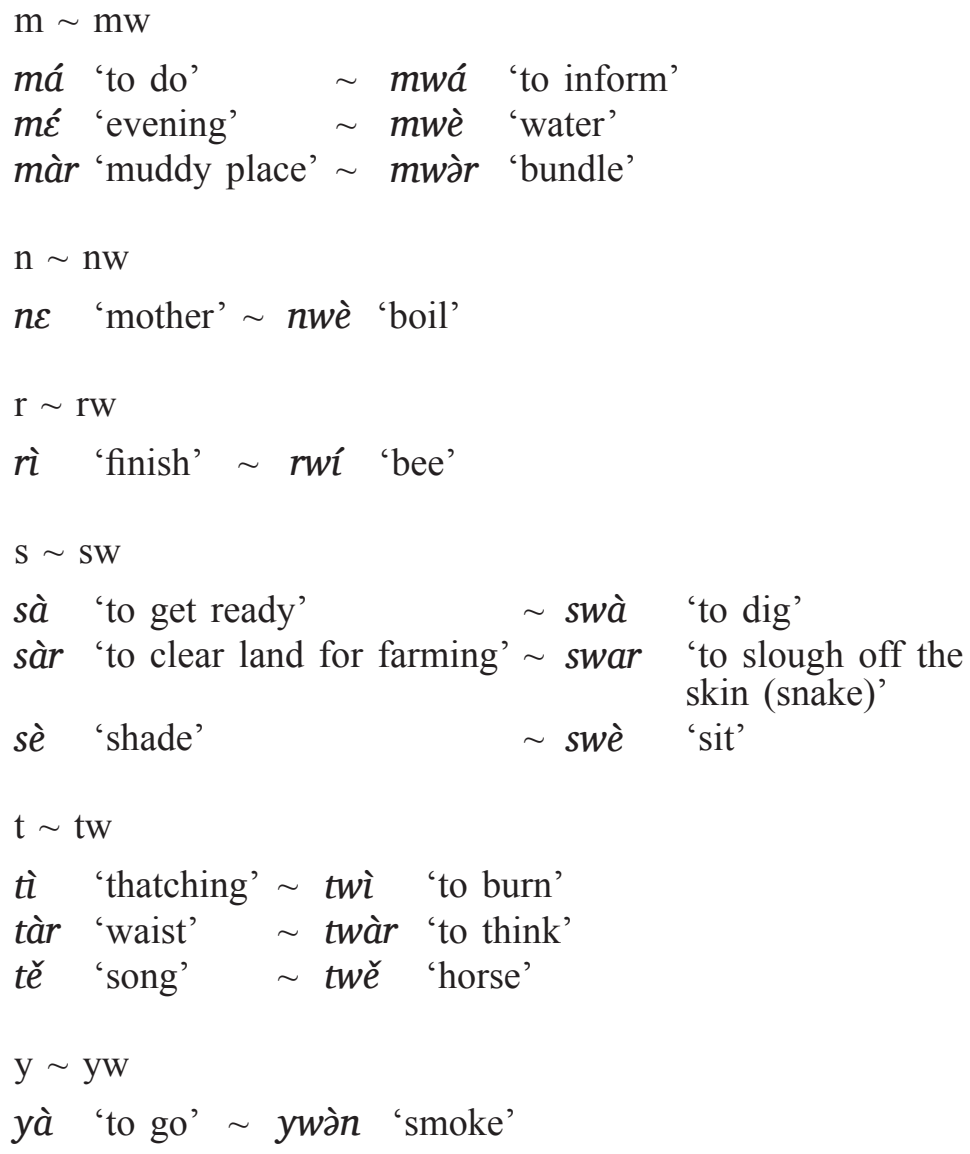

\subsubsection{Prenasalisation}

Nasals in word-medial position are homorganic with the following consonant. These probably arise from combinations of the root and a suffix, which has now become unproductive and bound to the root. The most common combinations are $/ \mathrm{mb} /$ and $/ \mathrm{nt} /$. Examples of these are as follows (see Table 6). 
Table 6

\section{Examples of prenasalised consonants in Kitole}

\begin{tabular}{ll}
\hline sg. & \\
bwàmbè & 'antelope' \\
dìtwambrr & 'swearing' \\
fùmbà & 'poor quality crops reserved for later in the season' \\
kámbí & 'rooms' \\
kàmbìr & 'money, iron' \\
pl. & \\
dàntil & 'bundle of cornstalks' \\
bétúkwántì & 'small rams' \\
bíntu & 'towns' \\
fántì & 'places' \\
\hline
\end{tabular}

The homorganic principle can be seen most clearly with the first person singular pronoun, which is N, i.e. $/ \mathrm{m} /, / \mathrm{n} /$ and $/ \mathrm{y} /$ according to the following consonant. Thus:

- $\mathrm{m}$ precedes $\mathrm{m}, \mathrm{b}$,

- $\mathrm{n}$ precedes $\mathrm{t}, \mathrm{l}, \mathrm{r}, \mathrm{c}$,

- $\mathrm{y}$ precedes $\mathrm{y}, \mathrm{k}, \mathrm{w}, \mathrm{y}$.

\subsubsection{Syllable and word structure}

The major syllable structures are $\mathrm{V}$ and $\mathrm{C}\left({ }^{\mathrm{w}}\right) \mathrm{V}$. Nasal prefixes could be analysed as $\mathrm{C}$, but as they do not bear independent tone, this remains controversial. Table 7 shows the word structures so far recorded.

Table 7

\section{Canonical Kitole word structures}

\begin{tabular}{lll} 
Structure & Kitole & Gloss \\
\hline V & a & 'on, in, at, on top of' \\
VCV & acá & 'purse' \\
VCVC & aràm & 'never'
\end{tabular}


End of Table 7

Structure Kitule Gloss

\begin{tabular}{|c|c|c|}
\hline $\mathrm{CV}$ & $b a ̀$ & 'to look for, to seek, to search' \\
\hline $\mathrm{CVC}$ & bàl & 'thick beer made from guinea-corn' \\
\hline $\mathrm{CVCV}$ & kwàdà & 'faeces' \\
\hline CVCCV & bàrtù & 'to tease' \\
\hline CVCVC & bèkán & 'to bring' \\
\hline CVCVCV & bákásì & ‘baboon’ \\
\hline
\end{tabular}

KItole has no syllable initial consonant clusters, although CC sequences at morpheme boundaries are common.

\subsection{Tones}

Kitole has three level tones, and glide tones that arise from sequences of level tones. The basic conventions are as follows:

— high: ',

- mid: unmarked,

- low: ',

— rising: ${ }^{\sim}$,

- falling: ^.

It is assumed in this paper that the basic tone-bearing unit (TBU) is a single vowel, and that bimoraic sequences of two similar vowels can therefore bear either similar or dissimilar tones.

Some examples of minimal triplets illustrating the three toneheights:

$\begin{array}{llll}\text { fúr 'grave' } & \sim \text { fur } & \begin{array}{l}\text { 'to bury' } \\ \text { kúl 'trap' }\end{array} & \sim \text { fùr 'stomach' } \\ \text { kwí 'clear liquid } & \sim k w i & \begin{array}{l}\text { after women' } \\ \text { on beer' }\end{array} & \sim \text { kùl 'sword' }\end{array}$


Contour tones are rare and unpredictable but in all cases the syllable coda is a sonorant. For example: bwăl 'to persist', câm 'guinea-corn', fŭl 'to cheat', kèr 'sound, noise'. They probably arise from compression of VV sequences that are pertained in other words': fwèé 'pullet', kàár 'pied crow'.

Melodies at the word level are very diverse and only a few observations can be entered here. Tone melodies on disyllabic words exhibit all possible combinations, as shown in Table 8.

Table 8

Diversity of tone melodies on disyllabic word

\begin{tabular}{lll} 
Melody & Kitole & Gloss \\
\hline HH & délán & 'death' [Baule dial.] \\
MM & bwaram & 'tiredness' \\
LL & dèlàn & 'praise' \\
HL & dókàn & 'to make peace' \\
LH & bwàrán & 'Well done!' \\
LM & càbtū & 'food' \\
HM & bwésm & 'childishness'
\end{tabular}

Trisyllabic roots, which are predominantly nominals, have a strong tendency to exhibit LLL tone patterns as in Table 9.

Table 9

\section{Kitole LLL melodies}

\begin{tabular}{ll} 
Kitule & Gloss \\
\hline bàbùnè & 'orphan' \\
bèkwàmì & 'small ram' \\
bìyìlìm & 'truth' \\
bwànbwàyè & 'sorrow'
\end{tabular}

${ }^{1}$ One reviewer states: "The data strongly suggests that the Tone Bearing Unit is the mora, and coda sonorants are moraic". The author considers this unlikely and stands by his interpretation. 


\section{End of Table 9}

\begin{tabular}{ll} 
Kitole & Gloss \\
\hline kàfàrè & 'agama lizard' \\
kàfwìnì & 'annoyance' \\
sìkìmì & 'to lift down' \\
\hline
\end{tabular}

This may reflect a historical pattern of Low-Tone prefixes which have the effect of lowering the remainder of the stem.

\section{Nominal morphology}

\subsection{Overview}

Kitule is an Adamawa language and like most members of this family its original noun-class system would have been marked by suffix alternations. Adamawa is in turn a branch of Niger-Congo which exhibits noun-class affix alternation and often concordial agreement processes, although in many cases this has broken down or been re-interpreted. Greenberg (1977) presents clear evidence for the movement between prefix and suffix and it is generally accepted that both Gur and Adamawa are characterised by suffixing. In relation to number-marking, Kitvle noun morphology is extremely complex, driven by the near collapse of a regular series of alternating suffixes. This system appears to have undergone major restructuring and Kitole is unusual in having prefixes, infixes and suffixes, and often there are two alternations in the same word (see also Kleinewillinghöfer 2006). The result is a highly unpredictable system of nominal plurals. Many of the noun stems incorporated eroded affixes, which have then been subject to affix renewal. While the elements in a particular singular and plural class can usually be identified, multiple combinations are possible. In addition, plurals undergo highly complex tone-changes, making it difficult to assign an underlying tone to an affix. All the hypotheses explored below to explain the patterns of number marking should be regarded as tentative, especially as in many cases only a single example exists. 


\subsection{Morphemes marking number in Kitzle}

3.2.1. Singular affixes

KItole singular affixes fall into four categories (Table 10).

Table 10

Kitole singular affixes

Class Position Realisations

CV- prefix kə-, dI-

$-\mathrm{N} \quad$ suffix $-V \eta$

$-\mathrm{R} / \mathrm{L} \quad$ suffix $\quad-V r,-V l$

$-\mathrm{V} \quad$ suffix $\quad-E,-I[?],-V y$

The $k \partial$ - affix only appears as a prefix and only in alternation with ta-, as shown below:

sg.

kàbán

pl.

kàdry

tàbayri

'hill'

kadwaku

tadínrì

'platform raised on mud or blocks'

kàkàn

tadwákárì 'rope'

tàkànrì

'handle'

Niger-Congo roots typically have a CVCV root with a CV affix. Words such as sg. kabàn $\sim$ pl. kabakù 'judgment', sg. carkっ pl. cartuksy 'okra' have a $-k V$ number marking suffix. It is possible that in words such as sg. kidike $\sim$ pl. kidiketi 'bat', sg. kadwaku $\sim$ pl. tadwákárì 'rope', sg. kıfíku pl. tîfíkrrı 'clan' there is an unproductive infixed $-k V$ suffix which has now become bound to the stem.

The singular prefix $d I$ - alternates with $t I$ - in the plural:

sg. pl.

dibál trbalm 'skin'

dìkâl tíkàlí 'bow'

díkulan tíkùlànì 'fighting' 
Kitole has a singular nasal suffix $-N$, usually realised as $-V \eta$, although alternating with a wide variety of plural suffixes:

sg. pl.

bàrày bàròn 'flat cakes made from fermented locust-bean seeds' bìyày bártu 'arrow'

dùwày dùy 'locust bean tree'

falán falí 'hand'

kIsayan kIsayı 'euphorbia [cactus]'

Words such as sg. kàrayé $~$ pl. kàrayétt 'centipede', sg. dìyakan $\sim$ pl. tìyákànì 'guinea-worm' are then analysed as incorporating frozen $-\mathrm{NV}$ nasal suffixes in the stem.

Kitule has a final $-r / l$ suffix in singulars which can alternate either with $-b i$ or $-t U$ in the plural:

sg. pl.

bwír bwíbí 'well'

dikír tikíbí 'bush'

dìkwel tìkwébI 'anus'

dòr dítu 'person who shows occasional bursts of madness' kúl kứtú 'trap'

Its probable origin is an eroded $-r V / l V$ suffix which is still present as a fossil form in words such as sg. kàkùrì pl. kàkùrèti 'heap, pile',

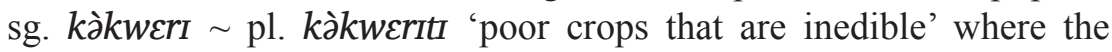
suffix has been incorporated into the stem. In these examples the -Ir suffix has been incorporated and a new plural suffix $-I$ has been added in the plural: sg. dìtwambrr pl. tìtwàmbìrì 'swearing' sg. kàmbìr pl. kàmbìrı 'money, iron'.

Kitule has at least two singular vowel suffixes, $-E(\mathrm{e} \sim \varepsilon)$ and $-I$ $(\mathrm{i} \sim \mathrm{I})$. These cannot always be reliably distinguished from frozen $-\mathrm{CV}$ affixes.

Kitole has a mid-front vowel suffix $-E$ which shows harmony with the vowel of the stem: 


$\begin{array}{lll}\text { sg. } & \text { pl. } & \\ \text { bàbùnè } & \text { babùmbu } & \text { 'orphan' } \\ \text { bèwừc } & \text { bétíwứrì } & \text { 'finger' } \\ \text { bìnè } & \text { bìnI } & \text { 'granary' } \\ \text { fwìy } & \text { futI } & \text { 'soup' }\end{array}$

It is conceivable that not all cases of final $-E$ have the same origin. For example, the -re in 'finger' above might be a former $-r V$ affix. Only further examples will clarify this issue.

Evidence for a true $-I$ suffix in nominal singulars is less certain. All the cases below might also be uneroded -CV suffixes:

$\begin{array}{lll}\text { sg. } & \text { pl. } & \\ \text { bèkwàmì } & \text { bétúkwánti } & \text { 'small ram' } \\ \text { bàlí } & \text { bàltı } & \text { 'tip of pointed object' } \\ \text { kàbìlI } & \text { kàbılett } & \text { 'fresh cowpeas' }\end{array}$

However, other evidence from fossil morphemes provides possible support for such an affix. Long vowels such as in dì (only sg. form) 'sky', sg. kî pl. kiiní 'ladle' may be stem plus -I suffix. CwI sequences, as in sg. kàkwi $\sim$ pl. kàkwati 'seed' may represent an orginal stem such as $k ə k u$ with an $-I$ suffix which has beomce assimilated. It is even possible that words such as sg. kayé $\sim$ pl. $k a t b u$ 'co-wife' contain an original $-I$ suffix, assimilated after a vowel and then resuffixed with $-E$ : sg. kákùmè $\sim$ pl. kákumetí 'epidemic, plague'.

There is a single example of what may be a $-d U$ suffix, although lack of other examples makes this uncertain: sg. dìbìdù pl. tỉbìdàrì 'question'.

Apart from the $b V$ - prefixes described above, Kitole has bVdiminutive prefix which precedes noun-class affixes and a high-tone which alternates with the plural form. These diminutives are related to the widespread Niger-Congo root -bi for 'child, small'. Since it is retained in plurals it cannot be regarded as part of the nominal affix alternation system. However, where the prefix is used, indicating 
diminutive, a $-t V$ - affix follows it, which suggests a $\emptyset$ - $t V$ - alternation preprefixed with the diminutive, as in the following examples:

$\begin{array}{lll}\text { sg. } & \text { pl. } & \text { Gloss } \\ \text { bèkìtì } & \text { bétátíní } & \text { small stick } \\ \text { bèkwàmì } & \text { bétúkwántì } & \text { small ram } \\ \text { bèwùre } & \text { bétŕwúrì } & \text { finger }\end{array}$

\subsubsection{Plural affixes}

Kitule plural affixes fall into four categories, CV, $-\mathrm{R} / \mathrm{L},-\mathrm{N}$ and $-\mathrm{V}$ (Table 11).

Table 11

Kitole plural affixes

\begin{tabular}{lll} 
Class & Position & Realisations \\
\hline$-\mathrm{CV}$ & suffix & $-t I,-r I,-n I,-b V,-y I$ \\
$-\mathrm{R} / \mathrm{L}$ & suffix & $-V r,-V l$ \\
$-\mathrm{N}$ & suffix & $-V n,-V m$ \\
& infix & $-\eta-,-m-$ \\
$-\mathrm{V}$ & suffix & $-a[?],-I,-V y$ \\
\hline
\end{tabular}

CV affixes are followed by an underspecified vowel, either I or U, which usually harmonises with the ATR value of the stem vowels.

The most common Kitole plural is formed by the addition of - $t I$ where $\mathrm{I}$ is $i / I$, effectively a $-\emptyset /-t I$ alternation:

sg. pl.

acá acátí 'purse'

be betr 'young animal'

kàár kàárti 'pied crow'

bw⿳亠े bwètì 'something kept aside for a special purpose' cûy cúntì 'mosquito'

In some cases, $-t I$ can alternate with a $-\mathrm{V}$ suffix in the singular: sg. bàlí $\sim$ pl. bàltı 'tip of pointed object'. 
A common allomorph of $-t I$ is $-t U$, where $U$ is $u / v$. This occurs where the singular has final $-r$, which is deleted in the plural:

sg. pl.

dur dútú 'head'

fưr fútu 'place covered in thick grass'

kár kátu 'headpad'

Various types of assimilation can occur: sg. fwìỳ̀ $~$ pl. futt 'soup'. It is possible that fwìy $\dot{\varepsilon}$ is the realization of /fơ $-(\mathrm{y}) \dot{\varepsilon} /$ with epenthetic [y], which would make the alternation with /fu-ti/ regular.

Some nouns have singular $d I-/ t I$ - alternating prefixes:

sg. pl.

dìbál tubalm 'skin'

dìkâl túkàlí 'bow'

dîkulan tíkùlànì 'fighting'

Other nouns, however, conserve their $d V$ - prefix:

sg. pl.

díbwàl díbwàlan 'strolling'

dire direti 'hedgehog'

In one case, the ti- prefix is placed in front of an old de-prefix without assimilation: sg. dèlàn $\sim$ pl. tídèlàn 'praise'.

A small proportion of the numerous nouns with a ka- prefix also alternate with ta-:

sg. pl.

kàbán tàbayri 'hill'

kàdry tadínrì 'platform raised on mud or blocks to lie down'

kadwaku tadwákárì 'rope'

kəféćku taféćkárı 'hunting' 
At least one noun infixes -ta- between the two syllables of the stem. There are two possible interpretations of this. Either the second syllable is composed of frozen suffixes, or else this is an old compound and the apparent infixing is the nominal prefix on the second element. For example, the final - $t a$ of the stem in 'cat' was presumably originally a productive $-t V$ suffix. Before it became frozen, another affix was added to what was perceived as the true stem. However, -ta- was not deleted and another pluralising suffix was added producing a final -ay. Alternatively, in a word like càrk̀̀ 'okra' there were originally two distinct elements forming a compound, but the $t V$ - prefix was applied to the $-k \grave{j}$ - element before the number marking became fully lexicalised:

$\begin{array}{lll}\text { sg. } & \text { pl. } & \\ \text { bwàmbè } & \text { bwantrbwéy } & \text { 'antelope' } \\ \text { càrkj̀ } & \text { càrtùkjyy } & \text { 'okra' } \\ \text { kàlta } & \text { kàlt’̀tay } & \text { 'cat' }\end{array}$

$-r I$ only occurs as a suffix and only on a relatively small number of words. Where the singular has final $-\eta \eta$, the $-r I$ suffix is added. However, where the final syllable of the singular is $-d U$ or $-k U$, the vowel is assimilated, usually to -ə-:

$\begin{array}{lll}\text { sg. } & \text { pl. } & \\ \text { báy } & \text { bápri } & \text { 'mountain' } \\ \text { kàkày } & \text { tàkàyrì } & \text { 'handle' } \\ \text { càdù } & \text { càdàrì } & \text { 'exit of bush-rat hole' } \\ \text { dəkūdu } & \text { təkūdri } & \text { 'navel' } \\ d w a k u & d w \partial k \partial r i & \text { 'rope' } \\ \text { kəf́́ćku } & \text { təféćkárı } & \text { 'hunting' }\end{array}$

Occasional words appear to have a $-r I$ suffix, but this may be an $E \sim I$ alternation happening to follow $r$ - rather than an assimilation of the -rI: sg. bèwùre $\sim$ pl. bétŕwứrì 'finger'. 
$-n I$ only occurs as a suffix and only on a relatively small number of words. In all cases, this is a $-\varnothing /-n i$ alternation:

sg. pl.

bu buni 'small garden'

bùrà bùrànì 'corner, angle of an object'

fúrà furani 'corner of the house'

kayls kayloni 'deserted settlement'

kè keni 'borrow-pit'

It is cross-linguistically plausible to anayse $-r I$ and $-n I$ as allomorphs, since they occur with non-intersecting finals.

A $-b I$ suffix appears in alternation with either final $-r$ or final $-n$ in singulars:

$\begin{array}{lll}\text { sg. } & \text { pl. } & \\ \text { bwír } & \text { bwíbi } & \text { 'well' } \\ \text { díkír } & \text { tikíbí } & \text { 'bush' } \\ d I n & d r m b i & \text { 'name' }\end{array}$

A $-b U$ suffix is applied only to human nouns:

\begin{tabular}{|c|c|c|}
\hline sg. & pl. & \\
\hline dìr & dìbbù & 'fool' \\
\hline naye & nàtabu & 'women' \\
\hline$n \check{\varepsilon}$ & $n \dot{\varepsilon} b u$ & 'mother' \\
\hline sèlè & 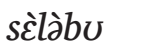 & 'elder' \\
\hline$t \check{\varepsilon}$ & $t \bar{c} b u$ & 'father' \\
\hline kè & tukebu & 'grandfather' \\
\hline kwàrè & fákwàrbú & 'enemy' \\
\hline
\end{tabular}

This occurs throughout the Tula/Waja group and is related to a widespread third person plural in Niger-Congo languages.

In the following case, the $-b U$ - is inserted as an infix, and a final $-m$ is also added:

sg. dààkù pl. dààbùkúm 'thief'. 
In this example, either this is an otherwise unparalleled initial reduplication, or else, the $b V$ - appears here as a prefix:

sg. bweshín pl. bàbweshín 'younger brother'.

A very few words have a $-y I$ suffix:

sg. pl.

dakwal tikwaliyi 'word'

nee nuyi 'eye'

It is assumed that nominal plurals with a final $-y$ are assimilated $-I$ suffixes rather than an eroded form of $-y I$. An alternation between $w U$ - and $y I-$ occurs as a prefix alternation on a few nouns:

sg. $\quad$ pl.

wùbare yìbarı 'wild animals'

wùkare yìkari 'old thing or person'

wutire yitiri 'the younger one'

Whether this $y I-$ is the same affix as the suffixed $-y I$ remains to be seen.

Kitole has suffixed and infixed nasals $\mathrm{n}$ and $\mathrm{m}$ as noun-class markers. It is not yet clear whether these are distinct from the rare functional suffixes $-n I$, rather than simply eroded forms. Table 12 presents examples of a final $-n$ plural suffix as follows.

Table 12

\section{Alternations of nasal suffixes}

\begin{tabular}{lll} 
sg. & pl. & Gloss \\
\hline bùràn & búrùn & 'sickness' \\
cún & cúnín & 'nose' \\
dassrr & tàsìràn & 'greeting' \\
dỉbál & trbalrn & 'skin' \\
díbwàl & díbwàlan & 'strolling' \\
dukứr & dukứtun & 'smth. wrapped in leaves presented as a gift' \\
\hline
\end{tabular}


$-\emptyset /-m$ suffixes are as follows:

sg. $\quad$ pl.

bwekíná bwebákinam 'maternal uncle'

bwélè bwélem 'youth'

fúr fúrèm 'burial'

Some alternations present examples of $-N$ infixes:

sg. pl.

dìdùn tıdúmun 'knee'

dasun tasumin 'dancing helmet'

dìsín tistmin 'loan'

cùòn cưứn 'hunger'

The bilabial infixes are strongly co-associated with the $d V-/ t V$ alternations in the prefix. One possible interpretation is that there was an original $-m$ number marking affix, as illustrated above. This became unproductive and was replaced by the $-\mathrm{VN}$ suffixes illustrated in Table 12. The form conón 'hunger' is unique in the lexicon but perhaps can be explained by an analogous process.

KiTule has the vowel suffixes $-a$ and $-I$.

The following $-a$ suffixes appear to be exceptional:

sg. pl.

dìnur trnúra 'laughter'

fwal fwàlà 'period when animals are being weaned'

$-I$ suffixes may either be added to the singular stem or alternate with an $-E$ suffix:

sg. pl.

bén bénI 'tongue'

bìnè bìn I 'granary'

bùkè bukí 'bead'

bwàl bwálì 'mouse'

cibe cibi 'clay dish'

cíñ cíní 'fish'

dibíl tibìilì 'road vehicle'

diffun tufúnI 'deaf person' 
Where $-I$ follows a vowel it is assimilated to $-y$ :

sg.

pl.

bwàmbè bwàntıbwéy carks cartuksy

'antelope'

dwàkà dwàkay

'okra'

kàlta

kàltàtay

'net (for carrying produce)'

kànà

kànay

kùlè

kùley

'cat'

'scorpion'

'boil on skin'

\subsubsection{Synthesis: Kitole noun-class markers}

Table 13 presents a provisional synthesis of the Kitule singular/plural noun-class affix pairings.

Table 13

\section{Kitole singular/plural pairings}

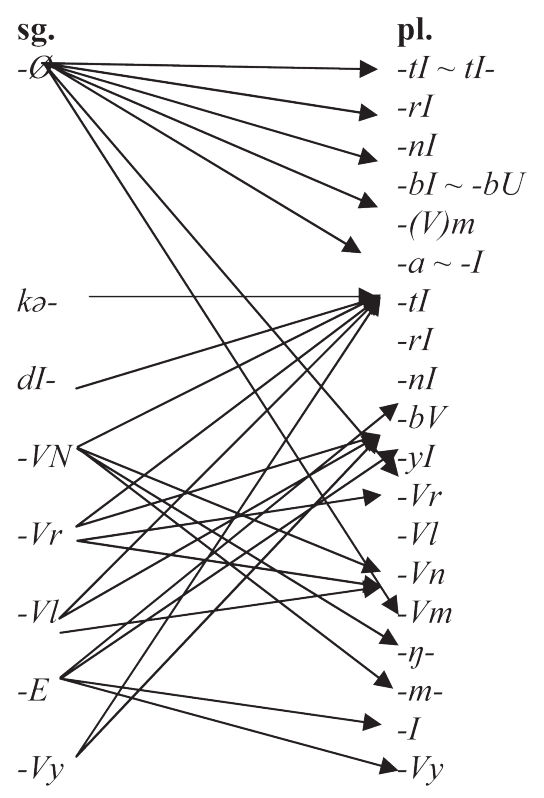

Doubtful affixes and reconstructed affixes are presently excluded, pending further evidence. 


\subsection{Demonstratives}

Demonstratives in Kitole show agreement but not segmental concord with the nouns they qualify. There is a broad semantic link between the pairings of demonstratives and nouns, but as the examples below show, there are many exceptions. This type of breakdown of concord has been noted for other languages in the group such as Awak (Yebu) (Jungraithmayr 1968/1969). Table 14 shows the principal pairings for the proximal demonstrative.

Table 14

\section{Kitole demonstratives}

\begin{tabular}{lll} 
'this' & 'these' & Class semantics \\
\hline wù & bàbù & 'human beings' \\
wù & yìyù & 'animals, fish' \\
dàdù & tátu & 'inanimates' \\
kàkù & yìyù & 'plants'
\end{tabular}

The examples below show some of the nouns and the class into which they fall.

i) Human beings: sg. bwé pl. bwésún 'child'. Thus:

bwé wù $\sim$ bwésún bàbù

'this child' 'these children'

However, this class also includes the following nouns:

$\begin{array}{lll}\text { sg. } & \text { pl. } & \text { Gloss } \\ \text { câm } & \text { camti } & \text { 'guinea-corn' } \\ \text { carks } & \text { cartuksy } & \text { 'okra' } \\ \text { cibe } & \text { cibi } & \text { 'clay dish' } \\ \text { cínc̀ } & \text { cínÍ } & \text { 'fish' }\end{array}$


ii) Animals:

$\begin{array}{lll}\text { sg. } & \text { pl. } & \text { Gloss } \\ \text { bákásì } & \text { bákásìti } & \text { 'baboon' } \\ \text { bèkwàmì } & \text { bétúkwántì } & \text { 'small ram' } \\ \text { bwàlà } & \text { bwàlàti } & \text { 'buffalo' } \\ \text { bwàl } & \text { bwálì } & \text { 'mouse' }\end{array}$

iii) Inanimates: butu (sg. only) 'ghost'.

iv) Plants:

sg. pl. Gloss

dùwàn dùi locust bean tree

kànàn kàní fan-palm tree

kèlàn kèlànı large pumpkin

\section{Conclusion}

Kitule has a relatively simple consontant inventory, characteristic of other languages in its group with only labialisation as a contrastive modification. There is limited evidence for doubled consonants, probably arising from former morpheme boundaries. The vowel system was clearly a former 5+5 ATR system, such as is retained in neighbouring Yebu and Kamo. However, the high vowels have begun to merge leaving some words no longer showing rigorous harmony. There is evidence for contrastive length in some vowels. The system of three tone heights is attested in other languages of the group.

Kitole has an extremely complex synchronic system of marking number in nominals, which derives from a much simpler prior system of suffix alternations, some of which have been re-analysed as part of the stem, become unproductive and then a new plural marking suffix has been added. In some examples, both alternations continue to operate, which gives the surface appearance of productive infixing. 


\section{References}

Blench, Roger M. \& Tula, Musa. 2009. A draft dictionary of Kitvle. Electronic ms.

Boyd, Raymond. 1989. Adamawa-Ubangi. In Bendor-Samuel, John. (ed.). The Niger-Congo Languages, 178-215. Lanham: University Press of America.

Boyeldieu, Pascal. 1980. Niellim et Tula (langues "Adamawa"): Concordances Morphologiques (pluriels nominaux). In Bouquiaux, Luc \& Guarisma, Gladys \& Manessy, Gabriel (eds.). Probèmes de comparatisme et de dialectologie dans les langues Africaines, 43-51. Paris: Centre National de la Récherche Sciéntifique.

CAPRO Research Office. 1995. Unmask the giant. Jos: CAPRO Media.

Casali, Roderic F. 2008. ATR harmony in African languages. Language and linguistics compass 2(3). 496-549.

Gebauer, Thomas. 1996. Facettes of terrace building in the culture of the Pero, Longuda and Tula people in north-eastern Nigeria. Berichte des Sonderforschungsbereichs 268 8. 125-129.

Greenberg, Joseph H. 1977. Niger-Congo noun class markers: prefixes, suffixes, both or neither. Studies in African linguistics 8. 97-104.

Hall, John S. 1944. From cannibalism to Christ: A story of the transforming power of the Gospel in Darkest Africa. New York - Toronto: Evangelical Publishers.

Huggins, J.A. 1925. An introduction to the Tula tribe of northern Nigeria, among whom our mission is now working. The Sudan witness 4. 12-13.

Jungraithmayr, Herrmann. 1968/1969. Class languages of Tangale-Waja district (Bauchi province, Northern Nigeria). Afrika und Übersee 52. 161-204.

Kleinewilllinghöfer, Ulrich. 1991. Die Sprache der Waja (nyan wịáùu). Frankfurt am Main: Peter Lang.

Kleinewillinghöfer, Ulrich. 1996a. Die nordwestlichen Adamawa-SprachenEine Übersicht. In Seibert, Uwe (ed.), Afrikanische Sprachen zwischen Gestern und Morgen, 80-103. Köln: Rüdiger Köppe.

Kleinewillinghöfer, Ulrich. 1996b. Relationship between Adamawa and Gur: the case of Waja and Tula. Gur Papers / Cahiers Voltaïques 1. 25-45.

Kleinewillinghöfer, Ulrich. 2006. Pluralbildung durch Infixe im Tula. In Winkelmann, Kerstin \& Ibriszimow, Dymitr (eds.). Zwischen Bantu und 
Burkina: Festschrift für Gudrun Miehe zum 65. Geburtstag, 139-148. Köln: Rüdiger Köppe.

Kleinewillinghöfer, Ulrich. 2014. Tula-Waja group: 100-Wordlist. Ms. 12 pp. Lukas, Johannes. 1955/1956. Grammar of the Tula Language (Northern Provinces, Nigeria). Afrika und Übersee 39. 101-118, 149-168.

Mu'azu, Mohammed Aminu \& Polo, Hannatu Ibrahim. 2015. Modern Tula dictionary. München: Lincom Europa. (Languages of the world: dictionaries 50.) 